\title{
The Sophism of the Life in Detrement of the Economy- Instrumentalized-in the Period of the Pandemic
}

\author{
Araujo Souza CK* \\ Centro Educacional Siqueira Campos, Brazil
}

*Corresponding author: Carlos Kleyvon Araujo Souza, Centro Educacional Siqueira Campos, 1117 Pernambuco St, Aracaju, Sergipe, Brazil, Tel: +55 7932591979; E mail: 666sac@bol.com. br

\section{Abstract}

The world is involved by issues of the most varied sciences, but there is one that has been growing a lot and bothers, in a good sense, the bioethics: The value of life. If that were the point of the discussion, it would already yield great discussions, however some circles and financial agents of speculative capital decided to launch the concept of life into the world of economics. This action totally transformed the clash, since the comparison between a moral concept and a perspective of understanding the world in this case the economic one becomes in itself unsustainable. Bioethics is the pertinent science to demonstrate how much incoherence there is in the comparison when it starts by manifesting the fiction, intentional, of the equivalence analyzed here. If the equivocal size between a moral issue and an economic issue were not enough, the second one carries with it the instrumentalization, since it serves the shady ends of a small group that has "speculative capital" as its characteristic. This analysis will address critical bioethics, based on the Frankfürt School with the aim of demonstrating not only the role, but the importance of bioethics in the subject that is current in the world: the pandemic caused by Covid-19. In addition and not less important, it is important to emphasize the relevance of reflection inherent to bioethics and of the consequences that arise from the instrumentalized economy, that is, with the objective of obtaining the highest profit margin without reasoning about its moral acts.

Keywords: Bioethics; Economy; Philosophy; Life

\section{A Bioethical Reflection of the Economy before the World Health Crisis}

This study will address the situation, actions and fundamentals of the bioethics in the world and at the moment in which humanity finds itself. For this, the basis used for its foundation will be based on the critical theory of the Frankfürt school, centered on the figure of the philosopher Jürgen Habermas. The theme of the theme will be the global health crisis, in this case the Covid-19 pandemic, facing the dilemma that caused many debates, which is the life versus economy dichotomy.
The theme proposes to expose a perspective of capitalism and its modus operandi, since such a system reveals peculiarities of humanity with regard to its selfishness, avarice and cruelty. These particularities serve as a basis for the instrumentalization of the economy and for the posture of the bioethics in the face of the situation. It is in the face of the current conjuncture, like this one of the pandemic, that bioethics must be present, observing, proposing studies and alternatives not for a way out because there is not! For the world health crisis currently plaguing humanity. Bioethics must be present to guide how humanity should walk this path, as it is what exists: path and no way out, so one must know how to walk it. 
It is necessary to analyze, with great care, the paradox that has arisen in the last weeks about the comparison between life and the economy, as if these two terms could be equal. Making use of J. Habermas' theory of communicative reason, here life will be taken as a concept in itself, absolute and unconditional. On the other hand, and now using the theory of this philosopher, we have a world perspective to understand how it Works in its territory, that is, in the financial market: the economic world.

In this way, we will reach the zenith that the present study proposes: that of analyzing the idea of comparison between two terms that at no time should be placed on an equal level. For the beginning of the analysis, according to Javier Sádaba, a common ethics or morality must be kept in mind, which is not the case with the comparison between life and the economic world, as follows in his quote where only: "(...) it is possible to have a universal moral or ethics only if bioethics is liable to universality, having previously a common ethics "Sadaba J, et al. [1]. In this way, it is questioned what is the common ethics that exists in an instrumented economy, I mean, an economy that does not reflect the morality of its actions, since it aims to "undertake all reasoning efforts to strategically establish the actions necessary to achievement this end" Cunha T, et al. [2].

\section{Until How Much is Life Absolute?}

The capitalist economic system created by humans and for humans was the most perverse and cruel way of reproducing the vile face of humanity from institutions, as a human extension, to legalize the illegitimate of all its ambition, greed and selfishness. Not that socialism or communism are very different, in their way of dealing, but here we will deal with the economic system that prevails in the contemporary world. As the emergence of capitalism occurred in the Western world, predominantly Christian, mention is made here of Peter Singer, who in turn implies the domain, in all its perspectives, in the "(...) acting in a way that causes fear and dread for everything that moves on Earth is not inappropriate; in fact, it is in accordance with a divine decree" Singer $\mathrm{P}$, et al. [3]. This quote is due to the fact that the discussion among Christians as to the meaning of the concession of "domination" of the world, of everything that inhabits it, as well as capitalism, which appropriates this maxim, trying to explain the unjustifiable in a vain way: comparing, in an artful way, life-absolute in itself-with a world perspective, in our case, the financial one.

On the one hand, we have the concept itself-the life-on the other, we have the perspective of a world understood from laws and principles governed for its ideal functioning. Now, it is the economist Richard Baldwin himself MSN, et al. [4] who separates quite clearly and concisely the incompatibility of such a comparison. There is no intelligible comparison between moral and economic issues. Such issues do not mix, as the expert says that this conflict is a way to circumvent the lack of management and logistics on the part of government officials, since they do not have the technical capacity to lead the health system crisis.

The question is: Where is bioethics in this tangle of worlds that should in no way be substantiated? We would say, in the first place, that life is absolute in itself, that it does not need to have any relationship, and that it is not capable of being instrumentalized, therefore it has value per si. That, secondly, the economic perspective of the world is a way of understanding it, that is, an understanding that cannot stand on its own, it needs principles and laws created from the human intellect. And thirdly, it is the task of bioethics to verify and denounce the instrumentalization of the economy, whose purpose is to manipulate and end-if necessary-in any form of life with a view to profit at any price.

\section{Instrumental Economics}

Who is the instrumentalization of the economy for? What are the intentions of the people behind institutions that have legitimately seized the power of decision-making power of States across countries through their economic power? How long will apathy be the result of so many socioeconomic differences without suspecting or questioning that there must be something wrong with the social structure created? In order to try to answer these questions, it is necessary to resort to the critical theory of the Frankfürt School, more specifically to Jüurgen Habermas. In order to substantiate this criticism, he affirms that history is indispensable, since through his knowledge, the same mistakes will not be repeated. With this, Habermas forms the communicative rationality, which is characterized by the form (...) to coordinate collective actions based on free dialogue between those involved in a given situation to be regulated, capable of opposing the instrumental rationality of these powers. The conditions of intercomprehension among the participants of a given discussion would be supported by the recognition of the validity of the arguments addressed to the three worlds that make up a certain universe of knowledge: the objective world linked to the contents of verifiable truths (empirical or scientific); the social world, linked to sociocultural characteristics and formal or informal rules of conduct in the context of the situation to be regulated; and the subjective world linked to the authenticity of the participants in the discussion in demonstrating acceptance of the rational strength of the best argument. (...) When this happens, decisions result in actions called communicative actions and are directly opposed to strategic actions proper to instrumental rationality. Cunha T, et al. [2]. 
This theory aims to expose and oppose instrumental rationality, in our case, economics as an instrument to achieve a certain end, devoid of any reflection on the morality of its own actions. Now, as seen in some countries, the dichotomy "life versus economy" was invented without the slightest moral concern of the consequences they cause on people's lives and, consequently, on all living beings on the planet. It is already inconceivable the idea of using the economy as an instrument, since there is no bioethical concern with the lives that will suffer the consequences of actions taken unthinkingly. It becomes bizarre when the absurdity of the idea of comparison between something absolute and a world perspective was exposed, so that there is behind all this chaos created purposely and methodically power relations with the objective of conquering territory, understand, by consumer market.

It is necessary, more than at any other time in history, that bioethics make itself heard, that it be present either in schools, in laboratories, or in debates and meetings of heads of countries so that actions regarding the direction of humanity do not continue to be taken without reflection and without any moral.

\section{Conclusion}

The analysis proposed by this text focused on the deceit, on purpose, on the comparison between life and economy. It was shown how sophist this question was when we started to expose in parts what the financial market actors tried to propose as true. With the world in recession, the pandemic would come in handy as a pretext to raise the maximum profit by opposing life, by undervaluing it.

What financial operators did not count on was that people trained for their own market would have sufficient morale to separate what should not, at any time, have been put side by side. Authorities on the subject, such as Richard Baldwin, provoked a reflection by exposing in a forceful way that a moral issue cannot in any way be posed and compared to a financial issue, not when what is at issue is the life. Despite having a certain financial value, from the perspective of the economic world, life is a concept in itself, it is absolute, it does not need any relationship or a law created from the human intellect to make itself understood.

It was seen how necessary bioethics is essential for the planet, read the owners of speculative capital, to have a minimum of awareness. We say this in the sense that reasoning is used to reflect the morality of actions, as we inhabit a living being, the planet Earth, and as responsible for it and for all those who inhabit it, we have the moral duty of zeal. We are the only race that inhabits the Earth that has reason, so let us use it for the best, to become better, so that we can become human, because until now we are learning ${ }^{1}$ to be human-paraphrasing Eduardo Marinho².

\section{References}

1. Sadaba J (2005) Bioethics and democracy. Revista Internacional de Pensamiento Político 1(1): 225-237.

2. Cunha T, Lorenzo C (2014) Bioetica global na perspectiva da bioetica critica. Rev Bioet 22(1): 116-125.

3. Singer $P$ (2006) Practical ethics. Human and social sciences, Philosophy, Ethics, General, São Paulo, Brasil, pp: 400.

4. MSN (2020) The corona virus's double curve says that choosing between saving lives or saving is a false dilemma.

\section{Endnotes}

${ }^{1}$ (...) es posible tener una moral o ética universal puesto que sólo es posible una Bioética Universal si tenemos previamente una ética común.

${ }^{2}$ (...) "agir de modo a causar temor e pavor a tudo o que se move na Terra não é impróprio; de facto, está de acordo com um decreto divino".

${ }^{3}$ (...) de coordenar ações coletivas baseadas no diálogo livre entre os envolvidos em uma dada situação a regular, capaz de se opor à racionalidade instrumental desses poderes. As condições de intercompreensão entre os participantes de determinada discussão estaria apoiada no reconhecimento da validade dos argumentos dirigidos aos três mundos que conformam determinado universo de saber: o mundo objetivo ligado aos conteúdos de verdades verificáveis (empíricas ou científicas); o mundo social, ligado às características socioculturais e às normas de conduta formais ou informais no contexto da situação a regular; e o mundo subjetivo ligado à autenticidade dos participantes da discussão na demonstração de aceitação da força racional do melhor argumento. (...) Quando isso acontece, as decisões derivam em ações denominadas ações comunicativas e se opõem diretamente às ações estratégicas próprias à racionalidade instrumental. ${ }^{4}$ Author's griffin.

${ }^{5}$ Visual artist, writer and social activist. 
Annals of Bioethics \& Clinical Applications

\section{Endnotes}

$1 \quad$ (...) es posible tener una moral o ética universal puesto que sólo es posible una Bioética Universal si tenemos previamente una ética común.

2 (...) "agir de modo a causar temor e pavor a tudo o que se move na Terra não é impróprio; de facto, está de acordo com um decreto divino".

${ }^{3}$ (...) de coordenar ações coletivas baseadas no diálogo livre entre os envolvidos em uma dada situação a regular, capaz de se opor à racionalidade instrumental desses poderes. As condições de intercompreensão entre os participantes de determinada discussão estaria apoiada no reconhecimento da validade dos argumentos dirigidos aos três mundos que conformam determinado universo de saber: o mundo objetivo ligado aos conteúdos de verdades verificáveis (empíricas ou científicas); o mundo social, ligado às características socioculturais e às normas de conduta formais ou informais no contexto da situação a regular; e o mundo subjetivo ligado à autenticidade dos participantes da discussão na demonstração de aceitação da força racional do melhor argumento. (...) Quando isso acontece, as decisões derivam em ações denominadas ações comunicativas e se opõem diretamente às ações estratégicas próprias à racionalidade instrumental. ${ }^{4}$ Author's griffin.

${ }^{5}$ Visual artist, writer and social activist. 